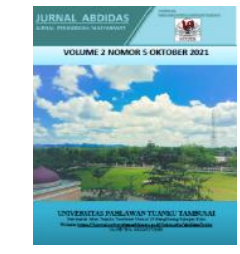

\title{
Pelatihan Pembuatan Pop Up Book dengan Memanfaatkan Limbah Sampah Sebagai Media Pembelajaran Sains bagi Guru Sekolah Dasar
}

\author{
Fitriani B ${ }^{1}$, Hijrawatil Aswat ${ }^{2}$, Mitra kasih La Ode Onde ${ }^{3}$, Eka Rosmitha Sari ${ }^{4}$, La Ode Musrafil ${ }^{5}$ \\ Universitas Muhammadiyah Buton, Indonesia ${ }^{1,2,3,4,5}$ \\ E-mail : bfitriani91@gmail.com ${ }^{1}, \underline{\text { hijrawati1171208@gmail.com }}{ }^{2}, \underline{\text { Mitralaodeonde@ @mail.com }}{ }^{3}$, \\ ekarosmitha@gmail.com ${ }^{4}$, musrafilode@gmail.com ${ }^{5}$
}

\begin{abstract}
Abstrak
Salah satu media yang dianggap tepat dalam menyampaikan pesan ialah media pop up book yang merupakan salah satu jenis media berbasis cetakan. Untuk mempersiapkan dan mematangkan desain media pop up book maka diperlukan adanya penguatan edukasi terkait desain media pembelajaran yang menarik, dapat menumbuhkan motivasi belajar siswa, dan dapat mencapai tujuan pembelajaran. Sehingga kegiatan ini bertujuan untuk memberikan pelatihan pembuatan media pop up book kepada guru di Sekolah Dasar. Sasaran dalam kegiatan ini adalah guru di SD Neger 2 Bataraguru Kota Baubau. Metode pelaksanaan kegiatan ini dirancang kedalam tiga tahapan pelaksanaan, yakni 1) kegiatan penguatan edukasi terkait pemanfaatan media dalam pembelajaran SAINS; 2) kegiatan simulasi dengan mempraktikkan secara langsung tahapan desain media pembelajaran pop up book dengan memanfaatkan limbah sampah; 3) kegiatan evaluasi, untuk melihat kemampuan akhir guru dalam membuat media popo up book secara mandiri. Kegiatan ini dianggap penting karena beberapa penelitian dan pengabdian kepada masyarakat sebelumnya terkait pengembangan media pembeljaran pop up book belum menekankan pada pemanfaatan limbah sampah, sementara itu salah satu hambatan guru dalam menyediakan media pembelajaran di kelas karena keterbatasan dana dalam menyediakan berbagai peralatan dan bahan yang digunakan. Sehingga melalui kegiatan ini, guru digiring untuk lebih memanfaatkan limbah sampah dengan menyulapnya menjadi media interaktif di kelas. Hasil Pengabdian kepada masyarakat menunjukkan hasil yang cukup memuaskan, berdasarkan analisis perbandingan sebelum dan setelah kegiatan dilaksanakan menunjukkan adanya keterampilan baru yang dimiliki oleh guru dalam mendesain media pembelajaran dengan memanfaatkan limbah sampah. Kata kunci: media pop up book, pemanfaatan limbah sampah, pembelajaran SAINS
\end{abstract}

\begin{abstract}
One of the media that is considered appropriate in conveying messages is the pop up book media which is a type of print-based media. To prepare and finalize the pop up book media design, it is necessary to strengthen education related to attractive learning media designs, can foster student learning motivation, and can achieve learning goals. So this activity aims to provide training on making pop up book media to teachers in elementary schools. The targets in this activity are teachers at SD Negeri 2 Bataraguru, Baubau City. The method of implementing this activity is designed into three stages of implementation, namely 1) strengthening education activities related to the use of media in science learning; 2) simulation activities by directly practicing the design stages of pop up book learning media by utilizing waste waste; 3) evaluation activities, to see the final ability of the teacher in making popo up book media independently. This activity is considered important because some previous research and community service related to the development of pop up book learning media have not emphasized the use of waste waste, meanwhile one of the obstacles for teachers in providing learning media in the classroom is due to limited funds in providing various equipment and materials used. So that through this activity, teachers are led to better utilize waste waste by turning it into interactive media in the classroom. The results of community service showed quite satisfactory results, based on a comparative analysis before and after the activity was carried out, it showed that there were new skills possessed by teachers in designing learning media by utilizing waste waste.
\end{abstract}

Keywords: media pop up book, utilization of waste, science learning

Copyright (c) 2021 Fitriani B, Hijrawatil Aswat, Mitra kasih La Ode Onde, Eka Rosmitha Sari, La Ode Musrafil.

\begin{tabular}{ll}
\hline Corresponding author: \\
Address & : Betoambari No.36 Kota Baubau \\
Email & $:$ bfitriani91@gmail.com \\
DOI & $:$ https://doi.org/10.31004/abdidas.v2i5.447
\end{tabular}

ISSN 2721-9224 (Media Cetak)

ISSN 2721- 9216 (Media Online) 
1181 Pelatihan Pembuatan Pop Up Book dengan Memanfaatkan Limbah Sampah Sebagai Media Pembelajaran Sains bagi Guru Sekolah Dasar - Fitriani B, Hijrawatil Aswat, Mitra kasih La Ode Onde, Eka Rosmitha Sari, La Ode Musrafil

DOI: https://doi.org/10.31004/abdidas.v2i5.447

\section{PENDAHULUAN}

Mengajar dalam konteks standar pendidikan, tidak hanya sekedar menyampaikan materi pelajaran, melainkan proses pengelolaan kelas atau manajemen kelas yang berkesesuaian. Aswat, 2019 (Peranan Manajerial Guru.Pdf, n.d.) Guru bertindak sebagai manager dalam mengelola lingkungan fisik kelasnya. Salah satu faktor pendukung keberhasilan proses belajar mengajar adalah lingkungan fisik kelas yang mendukung, melalui kemampuan guru memanajerial kelasnya dengan menciptakan kelas yang aman, nyaman dan menyenangkan bagi siswa sehingga siswa akan lebih termotivasi melakukan aktivitas belajar secara aktif. (Karso, 2019) Guru adalah instrumen utama dalam pendidikan yang berkualitas maka dapat menghasilkan siswa yang berkualitas juga, begitu pun sebaliknya. Guru yang tidak berkualitas akan menghasilkan siswa yang tidak berkualitas pula. Dengan demikian untuk menghasilkan kegiatan pembelajaran yang berkualitas maka diperlukan guru yang kreatif dalam menyajikan materi pelajaran, agar siswa memperoleh perubahan perilaku setelah mengikuti kegiatan belajar. Salah satu pendukung dalam keberhasilan belajar ialah tersampainya pesan atau materi kepada siswa dengan baik sehingga siswa dapat memahami sesuatu yang sedang dipelajarinya. Untuk membantu penyampaian pesan ini diperlukan saluran berupa media untuk mempermudah penyampaian pesan, mengatasi hambatan-hambatan komunikasi, dan mengkonkritkan sesuatu yang abstrak. Menurut (Ninla Elmawati Falabiba, 2019) media pembelajaran adalah segala sesuatu yang dapat digunakan untuk menyalurkan pesan (bahan pembelajaran) sehingga dapat merangsnag perhatian, minat, pikiran, dan perasaan peserta didik dalam kegiatan belajar untuk mencapai tujuan pembelajaran.

Media pembelajaran dapat memusatkan perhatian siswa dan memberikan kemudahan kepada siswa untuk memahami materi pelajarannya, terutama mata pelajaran IPA yang bukan hanya penguasaan kumpulan pengetahuan yang berupa fakta-fakta, konsep-konsep, atau prinsip saja, akan tetapi suatu proses penemuan, cara mencari tahu tentang alam secara sistematis. Noviyanti,2017 (Astuti et al., 2020) pembelajaran sains memiliki peranan penting dalam memberikan pengalaman kepada siswa ditinjau dari dimensi sains sebagai pengetahuan, proses dan produk, penerapan atau aplikasi, serta sarana pengembangan sikap dan nilai-nilai ilmiah. (Supardi, 2017) untuk pembelajaran sains menfokuskan pada interaksi antar siswa dengan objek di alam secara langsung, sedangkan guru hanya bertindak sebagai fasilitator yang menciptakan kondisi dan menyediakan sarana agar siswa dapat mengamati dan memahami objek sains. Sehingga penyampaian materi yang berbau SAINS sangatlah membutuhkan media kongkrit yang dapat membantu siswa dalam mengembangkan imajinasi dan daya berpikir, sehingga memenuhi kebutuhan belajar siswa. Beberapa penelitian sebelumnya menunjukkan bahwa pengajaran dapat efektif apabila objek dan kejadian terkait dengan materi yang sedang 
1182 Pelatihan Pembuatan Pop Up Book dengan Memanfaatkan Limbah Sampah Sebagai Media Pembelajaran Sains bagi Guru Sekolah Dasar - Fitriani B, Hijrawatil Aswat, Mitra kasih La Ode Onde, Eka Rosmitha Sari, La Ode Musrafil

DOI: https://doi.org/10.31004/abdidas.v2i5.447

dipelajari dapat divisualisasikan secara realistik yang menggambarkan objek yang menyerupai. Salah satu media yang dapat meransang imajinasi siswa dan menarik perhatian siswa ialah penggunaan media pop up book. (Syofyan, 2020) mengemukakan bahwa pop up book adalah buku dengan unsur 3 dimensi serta media pembelajaran yang memiliki daya tarik karena didalamnya menyajikan hal-hal baru disetiap halamannya, sehingga dapat menimbulkan rasa takjub dan penasaran peserta didik saat membaca pop up book. Sejalan dengan (Arip \& Aswat, 2021) bahwa Pembelajaran yang dikemas dalam media pop up book akan memudahkan guru memberikan pemahaman kepada siswa terhadap pelajarannya dan menambah ketertarikan anak serta memicu kreatifitas anak setelah melihat objek tiruan, karena tersaji dalam bentuk tiga dimensi serta tampilan yang menarik dan menyerupai objek sesungguhnya namun dalam bentuk atau ukuran yang lebih kecil. Selanjutnya dalam penelitiannya tentang penggunaan media pop up book terhadap peningkatan hasil belajar siswa, menunjukkan hasil belajar yang mengalami peningkatan yang cukup signifikan serta aktivitas siswa selama proses pembelajaran terus mengalami perubahan kearah yang lebih baik. Pop up book dapat membangkitkan motivasi belajar siswa karena dalam penggunaannya dapat diserta dengan cerita yang menarik yang dekat dengan lingkungan mereka. (Shofiyah \& Wulandari, 2017) dalam media pop up book penggunaan ilustrasi, warna, dan tipografi disesuaikan dengan kesukaan anak sehingga anak merasa lebih akrab dengan karakter-karakter yang dibuat. (Setiyanigrum, 2020) ketika Pandemi Covid-19 berakhir, guru harus bekerja keras kembali untuk melaksanakan proses pembelajaran yang awalnya dilaksanakan secara online menjadi pembelajaran tatap muka atau langsung, sehingga diperlukan pemberian motivasi belajar kepada siswa untuk mengembalikan semangat belajarnya, sehingga media pop up book dianggap paling cocok untuk melengkapi kegiatan pembelajaran, karena selain menarik, juga dapat menyajikan sesuatu yang abstrak menjadi kongkrit. Media ini memerlukan kejelian dalam merancang desainnya karena gambaran ilustrasinya harus menarik dan juga sesuai dengan obyek yang digambarkan.

(Aswat et al., 2020) Untuk mendapatkan kualitas media pembelajaran yang baik agar dapat memberikan pengaruh yang signifikan dalam proses belajar mengajar, maka diperlukan pemilihan dan perencanaan penggunaan media pembelajaran yang baik dan tepat. Berdasarkan hal tersebut, sehingga kegiatan pelatihan ini dianggap penting untuk dilakukan mengingat beberapa kegiatan pelatihan serupa yang telah dilakukan sebelumnya oleh tim PKM lainnya, belum menekankan pada pemanfaatn limbah sampah. Berdasarkan kondisi awal di sekolah sasaran, pemanfaatan media pembelajaran pop up book belum pernah diaplikasikan dalam pembelajaran IPA, karena kurangnya sosialisasi secara menyeluruh kepada guru terkait media pop up book yang dapat menggambarkan materi pelajaran secara nyata dan menghadirkan ilustrasi materi yang tidak dapat digambarkan atau ditampilkan 
1183 Pelatihan Pembuatan Pop Up Book dengan Memanfaatkan Limbah Sampah Sebagai Media Pembelajaran Sains bagi Guru Sekolah Dasar - Fitriani B, Hijrawatil Aswat, Mitra kasih La Ode Onde, Eka Rosmitha Sari, La Ode Musrafil

DOI: https://doi.org/10.31004/abdidas.v2i5.447

objek aslinya dalam kelas. Terlebih lagi pembuatan media dianggap membutuhkan waktu yang cukup banyak dalam menyelesaikannya untuk satu kali pertemuan, membutuhkan dana dalam penyediaan alat dan bahan, serta membutuhkan kreatifitas tinggi dalam mendesainnya. Sehingga tim pelaksana kegiatan pelatihan bermaksud untuk mengedukasi guru dalam menciptakan karya media pembelajaran yang ramah lingkungan, ialah pemanfaatan limbah sampah yang disulap menjadi media interaktif didalam kelas. Selain ramah lingkungan, pemanfaat limbah sampah juga minim biaya, dan dapat diperkenalkan kepada siswa sebagai edukasi terkait limbah sampah yang dapat digunakan dan diaur ulang menjadi karya seni yang bermanfaat. Limbah sampah yang digunakan ialah sampah plastik dan kertas.

\section{METODE}

Sasaran dalam Kegiatan ini adalah guru di SDN 2 Bataraguru Kota Baubau berjumlah 8 guru perwakilan. kegiatan ini dilaksanakan disaat pandemic covid-19 sehingga dilakukan pembatasan peserta dan hanya diikuti oleh guru perwakilan yang selanjutnya menjadi pendamping bagi guru-guru lainnya dalam mengembangkan media pembelajaran. Metode pelaksanaan kegiatan melalui 3 tahapan, yakni: 1) penguatan edukasi, sebagai bentuk sosialisasi terkait pentingnya pemanfaatan media pembelajaran dalam kelas; 2) metode simulasi pembuatan media pop up book, dengan menyediakan beberapa bahan bekas pakai yang akan digunakan dalam mendesain media 3 )
Evaluasi, melihat dan menilai hasil karya guru dalam mendesain media pop up book.

\section{HASIL DAN PEMBAHASAN}

Situasi pembelajaran selama pandemi covid 19 mengakibatkan kondisi belajar yang tak biasa bagi siswa, bahkan beberapa peneliti menemukan fakta bahwa anak mengalami penurunan minat belajar selama pembelajaran tidak dilaksanakan di sekolah. Hasil penelitian (Yanti \& Sumianto, 2021) diperoleh bahwa pembelajaran dimasa pandemi covid-19, minat belajar siswa tidak sepenuhnya dapat dicapai sesuai dengan indikator minat belajar yaitu kesukaan, ketertarikan, perhatian, dan keterlibatan yang diakibatkan oleh beberapa faktor penghambat minat belajar itu sendiri seperti media pembelajaran, jaringan internet, fasilitas pembelajaran, peran orang tua, dan kualitas pembelajaran. Sehingga dimasa new normal ini, saat pembelajaran dilaksanakan secara tatap muka terbatas, maka diperlukan upaya guru untuk mengembalikan semangat belajar siswa, salah satunya melalui pemanfaatan media pembelajaran yang menarik dan mudah dipahami oleh siswa. Media pembelajaran yang dianggap paling tepat ialah media pop up book.

Penguatan edukasi dilaksanakan untuk memberikan gambaran umum kepada guru terkait pemanfaatan media pembelajaran dengan membawakan materi tentang 1) pentingnya melibatkan media pembelajaran di kelas; 2) kupas tuntas media pembelajaran yang sederhana dan menarik bagi guru pasca pandemic covid 19;3) merancang media pembelajaran SAINS. Materi 
1184 Pelatihan Pembuatan Pop Up Book dengan Memanfaatkan Limbah Sampah Sebagai Media Pembelajaran Sains bagi Guru Sekolah Dasar - Fitriani B, Hijrawatil Aswat, Mitra kasih La Ode Onde, Eka Rosmitha Sari, La Ode Musrafil

DOI: https://doi.org/10.31004/abdidas.v2i5.447

tersebut dibawakan oleh tim pelaksana kegiatan dengan memetakan masing-masing tugas, dimana 3 orang berperan sebagai pemateri, 1 orang bertugas sebagai moderator, dan 1 orang bertugas menyiapkan segala peralatan yang digunakan dan memastikan kegiatan berlangsung dengan menerapkan protokol kesehatan yang ketat. Kegiatan sosialisasi ini dilaksanakan diluar jam pelajaran dan berlangsung selama kurang lebih 2 jam yang dilaksanakan pada tanggal 26 juni 2021. Selama kegiatan sosialisasi terpantau peserta yang hadir sesuai dengan penugasan bagi guru yang akan mengikuti pelatihan sebanyak 8 guru dari masing-masing perwakilan guru kelas dan guru mata pelajaran. Peserta aktif dalam sesi sharing terkait kendala dan pemberian solusi seputar pemanfaatan media pembelajaran. Setelah mengikuti kegiatan penguatan edukasi ini, selanjutnya diharapkan dalam memasuki masa new normal melalui pelaksanaan pembelajaran tatap muka terbatas, guru dapat menyajikan kelas yang menyenangkan dan menghadirkan media-media pembelajaran yang unik dan interaktif didalam kelas, untuk menumbuhkan kembali motivasi belajar siswa dengan memancing rasa penasaran siswa sehingga ada keinginan untuk mencari tahu sendiri materi pelajarannya melalui diskusi kecil didalam kelas, sharing pendapat, dan kaitannya dengan kehidupan sehari-hari siswa.

Kegiatan selanjutnya dihari kedua yang dilaksanakan pada tanggal 27 juni 2021, dilaksanakan pelatihan pembuatan media pembelajaran pop up book dengan memanfaatkan limbah sampah. Kegiatan ini berlangsung selama 2 jam dan dilaksanakan diluar jam pelajaran, sehingga tidak mengganggu aktivitas belajar mengajar di sekolah maupun secara daring. Tahapan ini terdiri dari perencanaan, pelaksanaan, dan evaluasi. Tahap perencanaan dilaksanakan dengan menyiapkan segala sesuatunya yang mendukung kegiatan ini berlangsung sesuai dengan tujuan yang diharapkan, seperti menyiapkan peralatan protokol Kesehatan, menyiapkan alat dan bahan pembuatan media yang berasal dari bahan yang tidak terpakai lagi seperti gabus bekas, dos bekas, plastik, pita bekas dan kertas. Adapun peralatan yang disediakan yakni gunting, lem fox, lem lilin, cutter, penggaris dan alat tulis. Selanjutnya tahap pelaksanaan yakni dengan mensimulasikan tahap-tahap pembuatan media pop up book disertai cara pemilihan dan pemisahan bahan-bahan yang akan digunakan hingga terbentuklah media pembelajaran yang menyerupai buku namun Ketika dibuka setiap halaman maka akan membentuk suatu ilustrasi yang memberikan suatu gambaran materi yang dapat memberikan pemahaman dan menambah ketertarikan anak pada suatu materi pelajaran karena tersaji dalam bentuk tiga dimensi serta tampilan yang dapat bergerak sehingga menumbuhkan ketertarikan siswa. Tahapan pembuatan media pop up book didesain dengan 2 tahap yakni penyusunan materi dan penyusunan tampilan media seperti pembuatan flow chart, pembuatan storyboard. Membuat flow chart untuk menjelaskan secara detail tahapan yang menjelaskan isi dari sebuah proses alur kerja dari suatu sistem, tujuannya agar membantu proses 
1185 Pelatihan Pembuatan Pop Up Book dengan Memanfaatkan Limbah Sampah Sebagai Media Pembelajaran Sains bagi Guru Sekolah Dasar - Fitriani B, Hijrawatil Aswat, Mitra kasih La Ode Onde, Eka Rosmitha Sari, La Ode Musrafil

DOI: https://doi.org/10.31004/abdidas.v2i5.447

Analisa dalam memahami alur suatu program yang akan dibuat.

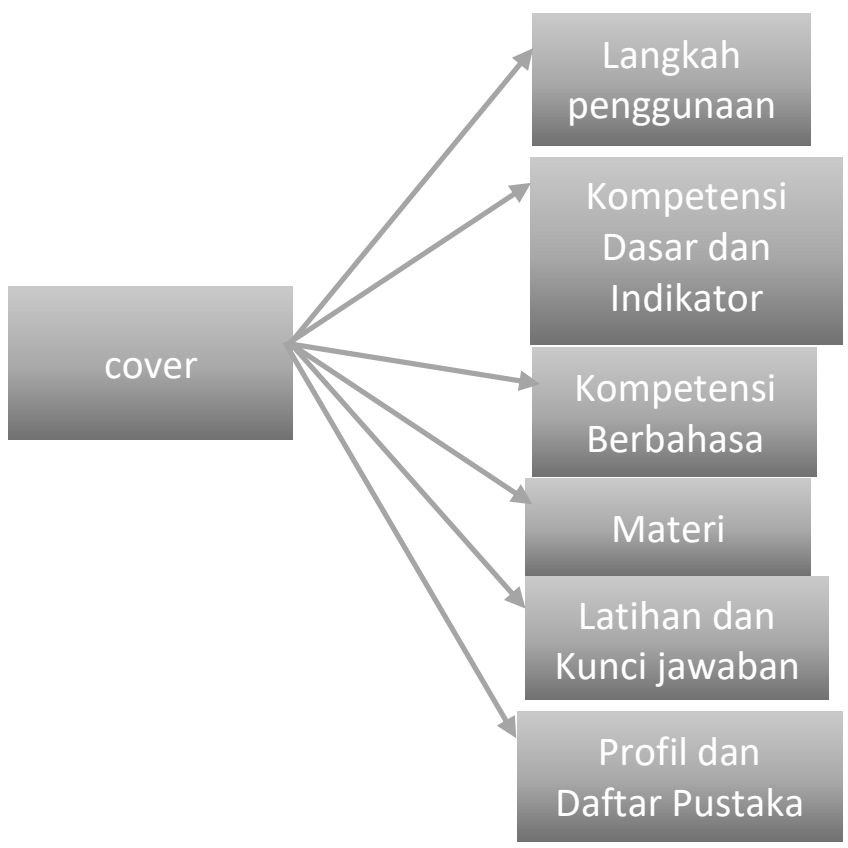

Gambar 1: flow chart media pop up book

Selanjutnya pembuatan story board merupakan sketsa yang dibuat secara beruntun untuk mempermudah penyampaian ide atau gagasan sebagai bentuk perencanaan. Dalam pembuatan story board dimulai pada pembuatan sketsa 1) tampilan awal pop up book (logo dan judul buku); 2) tampilan langkah-langkah penggunaan dengan berisi keterangan ilustrasi, judul, langkah penggunaan; 3) tampilan competence; 4) tampilan materi; 5) tampilan levocabulaire; 6) tampilan profil dan daftar pustaka. Tahap selanjutnya yaitu membuat visualisasi desain media berdasarkan story boar yang telah dibuat yang dilengkapi dengan materi yang telah ditentukan sebelumnya. Pada tahap ini keberhasilannya sangat ditentukan oleh pemilihan jenis gambar, ukuran, warna, font tulisan, dan konten.

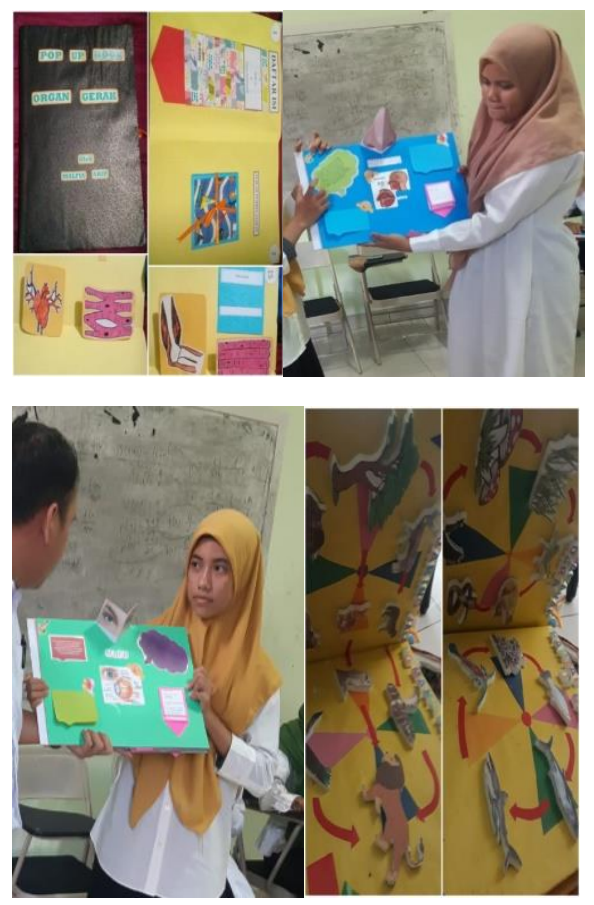

Gambar 2: media Pop up book

Bahan yang digunakan dari media ini terbuat dari gabus bekas, kertas manila bekas, karton, serta mengambil gambar dari koran, bungkusan plastik, majalah, dan menggunting huruf-huruf besar yang ada dan menyusunnya dalam bentuk judul materi. Estimasi waktu pelatihan cukup singkat sehingga praktik pembuatan media dilanjutkan diluar jadwal pelatihan, sehingga pembuatan ilustrasi setiap halamannya dilanjutkan oleh masing-masing kelompok guru dan dilaporkan hasilnya sebagai bentuk evaluasi dalam pembuatan media secara mandiri.

Evaluasi, dilaksanakan setelah kegiatan sosialisasi dan simulasi dilaksanakan, tujuannya untuk melakukan pengamatan secara langsung dan Penilaian terhadap hasil katya media yang telah 
1186 Pelatihan Pembuatan Pop Up Book dengan Memanfaatkan Limbah Sampah Sebagai Media Pembelajaran Sains bagi Guru Sekolah Dasar - Fitriani B, Hijrawatil Aswat, Mitra kasih La Ode Onde, Eka Rosmitha Sari, La Ode Musrafil

DOI: https://doi.org/10.31004/abdidas.v2i5.447

dibuat dan hasilnya menunjukkan perubahan yang cukup berarti karena secra mandiri guru telah berhasil melanjutkan dan menyelesaikan pembuatan visualisasi desain medianya berdasarkan rumusan story board sebelumnya.

Paparan tersebut mengaskan bahwa pelaksanakan kegiatan sosialisasi dan penguatan edukasi terkait pembuatan media pembelajaran SAINS jenis pop up book atau buku pop up di SD Negeri 2 Bataraguru sangatlah bermanfaat dan memiliki pengalaman tersendiri oleh peserta karena ada penambahan pengalaman terkait pembuatan buku pop up sesuai dengan ilustrasi dan tahapan pembuatannya.

\section{SIMPULAN}

Program sosialisasi terkait penguatan edukasi kepada guru dalam memanfaatkan media pembelajaran yang ramah lingkungan dan minim biaya terlaksana dengan sukses, dimana guru diberikan penguatan terkait penggunaan media dan dilanjutkan dengan simulasi pembuatan media SAINS berupa buku pop up yang berbentuk buku yang dapat memberikan visualisasi materi yang lebih menarik dibandingkan dengan buku paket pada umunya, sehingga untuk mencapai itu diperlukan adanya perencanaan yang matang dengan membuat flow chart dan story board terlebih dahulu, selanjutnya pembuatan visualisasi desain medianya berdasarkan materi yang telah dipilih, alur flow chart dan story board. Berdasarkan evaluasi yang telah dilakukan dapat diajukan beberapa saran sebagai berikut: 1) Bagi sekolah baiknya menyediakan berbagai sarana dan prasaran pendukung dalam penyediaan media pembelajaran, mengikutsertakan guru dalam kegiatan pelatihan lainnya dalam pembuatan media pembelajaran, mendukung pembuatan media paten yang dapat digunakan dalam jangka Panjang; 2) Bagi Guru, menumbuhkan jiwa kreativitas melalui pembuatan media yang dapat memanfaatkan limbah sampah yang masih layak pakai dan aman, menumbuhkan jiwa kepedulian diri terhadap kebutuhan belajar siswanya, terus berkarya dan mengembangkan diri dalam kegiatan pelatihan lainnya.

\section{UCAPAN TERIMA KASIH}

Kegiatan ini dapat terselesaikan dengan lancar dan sesuai target, tentu tak lepas dari dukungan berbagai pihak, terutama kekompakan tim dalam menjalankan tugas masing-masing dan dukungan dari pihak Sekolah Dasar Negeri 2 Bataraguru, serta dukungan dari Universitas Muhammadiyah Buton yang telah memberikan izin dan mensupport Kegiatan tersebut. Ucapan terimakasih kapada mahasiswa yang telah ikut serta berpartisipasi dalam kelancaran pelaksanaan kegiatan sekaligus menambah wawasan dan pengalaman di lapangan.

\section{DAFTAR PUSTAKA}

Arip, M., \& Aswat, H. (2021). Media Pop Up Book Untuk Meningkatkan Hasil Belajar Siswa Pada Mata Pelajaran IPA Di Sekolah Dasar. Edukatif: Jurnal Ilmu Pendidikan, $3(1)$, 261-268. Https://Doi.Org/10.31004/Edukatif.V3i1.329

Astuti, A. P., Mawarsari, V. D., \& Prihaswati, M. (2020). Pendampingan Guru Sains SD Melalui Pelatihan Pembuatan Media Pop-Up 
1187 Pelatihan Pembuatan Pop Up Book dengan Memanfaatkan Limbah Sampah Sebagai Media Pembelajaran Sains bagi Guru Sekolah Dasar - Fitriani B, Hijrawatil Aswat, Mitra kasih La Ode Onde, Eka Rosmitha Sari, La Ode Musrafil

DOI: https://doi.org/10.31004/abdidas.v2i5.447

Book Untuk Meningkatkan Literasi Baca

Tulis. JPM (Jurnal Pemberdayaan

Masyarakat), 5(1), 358-364.

Https://Doi.Org/10.21067/Jpm.V5i1.3257

Aswat, H., La, M., Onde, O., Madiani, L. O., Guru, P., Dasar, S., \& Buton, U. M. (2020).

Jenis Diorama Berbasis Tematik Integratif Di Sekolah Dasar. 1(5), 450-457.

Karso. (2019). Keteladanan Guru Dalam Proses Pendidikan Di Sekolah. Prosiding Seminar Nasional Pendidikan Program Pascasarjana Universitas PGRI Palembang, 12 Januari 2019, 2, 382-397.

Kemdikbud. (2020). Panduan Penyelenggaraan Pembelajaran Di Masa Pandemi COVID-19. Kemendikbud, 2019, 1-58. Https://Www.Kemdikbud.Go.Id/Main/Blog/ 2020/06/Buku-Saku-Panduan-PembelajaranDi-Masa-Pandemi-Covid19

Ninla Elmawati Falabiba. (2019). 済無No Title No Title No Title. 7(November), 14-25.

Peranan Manajerial Guru.Pdf. (N.D.).

Setiyanigrum, R. (2020). Media Pop-Up Book Sebagai Media Pembelajaran Pascapandemi. 2016, 2016-2020.

Shofiyah, N., \& Wulandari, F. E. (2017). Pelatihan Pembuatan Pop Up Book Sebagai Media Pembelajaran Sains Bagi Guru Taman Kanak-Kanak. Jurnal ABDI, 3(1), 32. Https://Doi.Org/10.26740/Ja.V3n1.P32-35

Supardi, K. (2017). Media Visual Dan Pembelajaran Ipa. Jurnal Inovasi Pendidikan Dasar, 1(10).

Syofyan, H. (2020). Pengembangan Media PopUp Book Pada. Jurnal Pendidikan Dasar, 11(2), 248-265.

Yanti, N. F., \& Sumianto, S. (2021). Analisis Faktor-Faktor Yang Menghambat Minat Belajar Dimasa Pandemi Covid-19 Pada Siswa SDN 008 Salo. Jurnal Pendidikan Tambusai, 5(1), 608-614. 